\title{
Has Programmed Trading Made Stock Prices More Volatile?
}

\author{
G. J. Santoni
}

If there must be madness, something may be said for having it on a heroic scale. - John Kenneth Galbraith, The Great Crash, p. 69.

$\mathbf{M}$ 1 Typical descriptions have characterized stock market behavior as "careening through" trading ranges, subject to "wild gyrations," and the product of "unexpected insanity."

The presumed source of the volatility is a trading strategy called "programmed trading."' This strategy, which essentially involves trading on small and shortlived price differences for the same group of stocks in the spot, futures and options markets, is not new. The introduction of stock index futures around 1982 and the application of computer techniques to monitor price differences and trigger trades between markets, however, are novel. These two innovations have reduced the cost of transacting among the markets, which has resulted in increased trading activity. The increased activity, the size of the trades made by individual players and the behavior of stock prices on days when stock index futures and options contracts

G. J. Santoni is a senior economist at the Federal Reserve Bank of St. Louis. Thomas A. Pollmann provided research assistance.

'See "Abreast of the Market" (1987) and Clark (1987). Other examples can be found in the Wall Street dournal on the following dates: January 16; January 20; January 23.

'See, for example, Stoll and Whatey (1987), Laderman and Frank (September 29, 1986); Laderman, et. al (April 7, 1986); Stoller (February 9,1987 ) and McMurray (February 12, 1987). mature (triple witching days have led many observers to conclude that this trading strategy has increased stock price volatility. ${ }^{3}$

The alleged increase in volatility has led both to closer scrutiny by the Securities and Exchange Commission and to calls for legislative action. ${ }^{4}$ In response to these concerns, the Chicago Mercantile Exchange voted recently to impose a 12 point daily price change limit on its Standard and Poor's 500 stock index fu tures contract and to move the expiration of the contract from the close to the opening of trading on quarterly expiration days. The latter was also adopted by the Chicago Board of Options Exchange for its Standard and Poor's 500 stock index option.

This paper examines the principles of trading between the spot and futures markets for stocks and the

\footnotetext{
3See, for example, Ladernan, et, al. (April 7, 1986) who assert that "Program trading, by its very nature, causes wild swings in the markets. ." p. 32; and "Program trading is a mixture of irony and mystery. . "breeds volatility." p. 33. "Triple witching" is a reference to the third Fridays of March, June, September and December. Stock index futures contracts and options on the futures expire on these days.

4See Lademan and Frank (September 29, 1986), p. 102. Stoller (February 9 , 1987) not only attacks programmed trading but all speculative activity. Borrowing from John Kenneth Galbraith (1955), he notes that "Wall Street, in these matters, is like a lovely and accomplished woman who must wear black cotton stockings, heavy woolen underwear, and parade her knowledge as a cook because. unhappily, her supreme accomplistment is as a harlot." p. 24
} 


\section{Glossary of Terms}

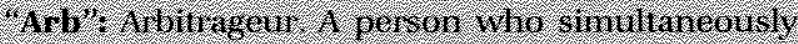
huys and sells the sane good in tho different markets:

Basis: The difference hetween the price of a fintures romiract and ithe pire or an equal quamily of the east instriment

\section{Hasis Point: 1 100 or one percent}

Rear Straddle: A spead in which the instrainen With the nearly matumy is sold and a simiar instrmment with a more distan mafmity is purchased

Bull stradlle: f spread in Which the instriment with the nearby maturity is purchased and a similar instriment whth a more distant maturity. is soldt.

CBT. Chicago Board of trade This exchange trades the Mator Market index fatures MMM.

Hot Money: the noney wealh tied up in proBram trading accounts.

IMM: tnternational Monetary Market This Chieago exchange trades the standard and Poors 500 nad f fumirs:

Interest Blasticity: 1 iatio of the pereentage change in the price of a thamcial instrument to hie percentage change in the interest discount nale:

Unwind: To reverse an earlier transaction.

KCBT: Kansas City Board of Trade. The exehange trades the Value Hine hatex I antures.

NWFE: New Jork rumes 16xchange. This exchange Hades the New tork stock lexehange Index ritines.

Programmed trading: the use of computer programs 10 analyse and trigger trading between stoek index fitures contracts, options on the index and the basket of stoeks roniamed in the indiex.

Spreadingt The simultaneous purchase and sale of No simiar financial instmuments of different maturity.

The. 01 Ethect: Measures Me change in the dollar value of an instriment that resuits from a change. of ane basis point in its jeld This depends on: the interest plasticity of the instruments.

Triple Witehing Hourthe time when options and fitures on stock indexes expire. This happens on the thind rvidisys of Mareh. June, september and Deceribor: claim that stock prices have become more volatile since stock index futures were first introduced. In addition, the paper examines whether programmed trading has contributed to increased stock price volatility.

The paper focuses on stock index futures rather than options because the market for options has been less active than the market for futures so the concerns noted above have focused on the more active futures market.s

sSee Belongia (1983) for a general discussion of options markets. Kawaller (1986), p. 1 and 3 , gives a general description of options on financial futures. Black and Scholes (1973) present a formal aralysis of option trading. Cinar (1987) discusses the effect of options on stock prices.

\section{STOCK INDEX PUTURES CONTRACTS}

Trading in stock index futures contracts was first introduced by the Kansas City Board of Trade on February 24, 1982. In April of the same year, the Chicago Mercantile Exchange, began trading a futures contract based on the Standard and Poor's Index of 500 common stocks. The introduction of both contracts was successful. By the end of 1982, daily trading volume in the Standard and Poor's futures contract, the most successful of the two, was running at about 20,000 contracts.

The success of the first two contracts induced other major exchanges to introduce similar instruments.

6See Schwarz, Hill and Schneeweis (1986), pp. 87-88. 


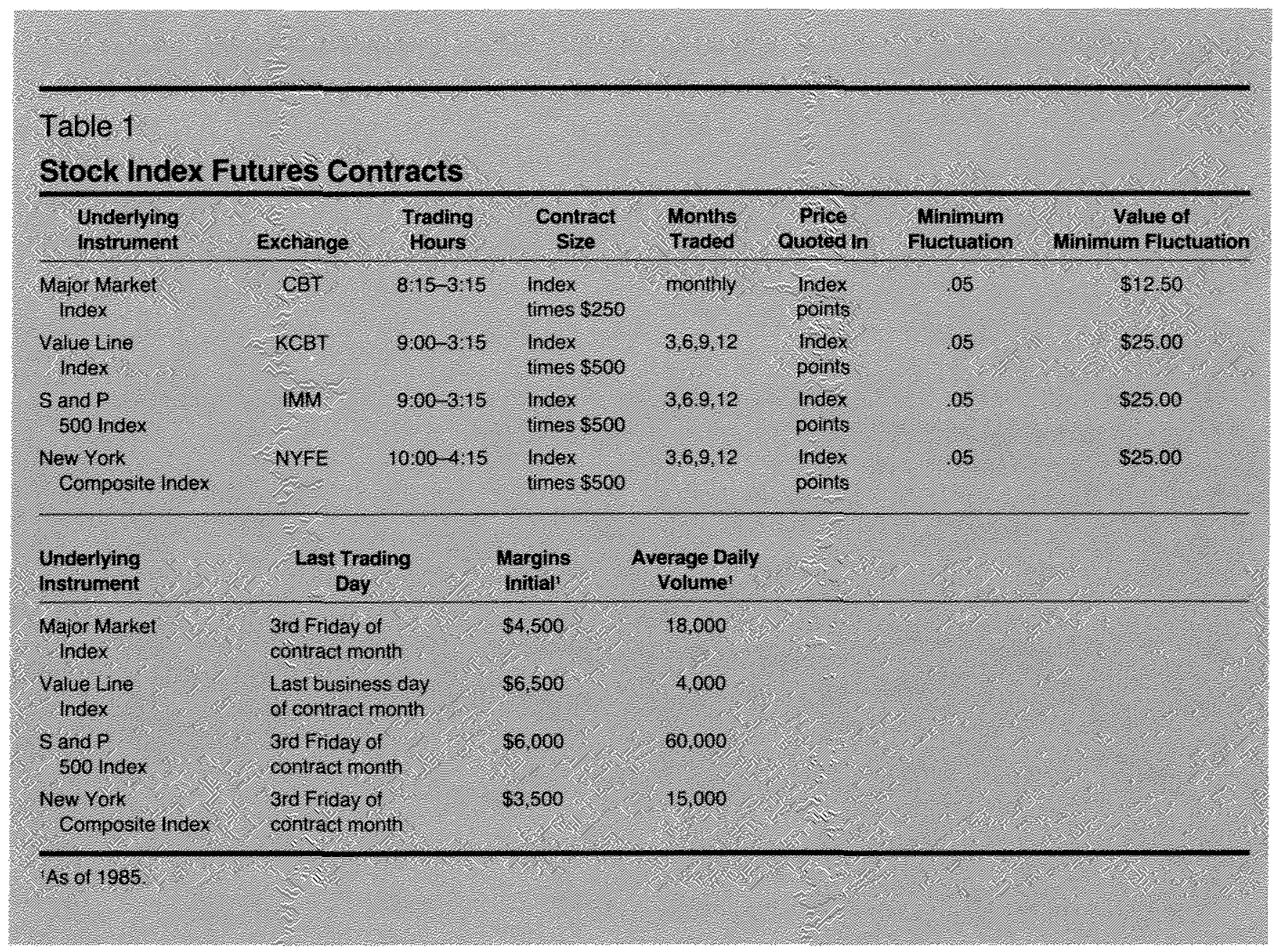

The New York Futures Exchange, a unit of the New York Stock Exchange, began trading a futures contract based on the New York Stock Exchange Composite Index in September 1983. Most recently, in July 1984 the Chicago Board of Trade began trading a futures contract based on the Major Market Index.

The Standard and Poor's $\mathbf{5 0 0}$ futures contract, which has been adopted by institutional investors, has experienced the most success. For example, the esti mated volume of trades in this contract was about 115,000 on April 14 of this year. The average daily trading volume of the S\&P 500 contract has been running at about 4 to 5 times the daily trading volume in the contracts based on both the New York Stock Exchange and Major Market indexes and about 15 times the contract based on the Value Line Index?

IIn addition, the Chicago Mercantile Exchange is currently trading a futures contract based on 100 stocks in the Standard and Poor's 500 Index (the "Mini" S\&P). Trading volume in this contract is very thin compared with those mentioned in the lext.

\section{Characteristics of the Contracts}

A futures contract on a stock index is an agreement between a seller (short position) and buyer (long position) to a cash settlement based on the change in the stock index's value between the date the futures contract is entered by the two parties and some future date. Table 1 summarizes some of the details regarding each of the stock index futures contracts mentioned above (see the shaded insert on page 22 for a general discussion of futures).

Table 2 presents the trading ranges for futures contracts on the Standard and Poor's 500 Index (S\&P Futuresi on February 6,1987 . The delivery dates of the contracts traded were the third Fridays of March, June and September of 1987. Notice that open interest is

BSee Schwarz, Hitl and Schneeweis (1986), p. 9. Stock index futures differ from commodity futures in that settlement of the former is always by cash. Stock index ftutures contracts make no provision for physical delvery of the stocks that are included in the index. 


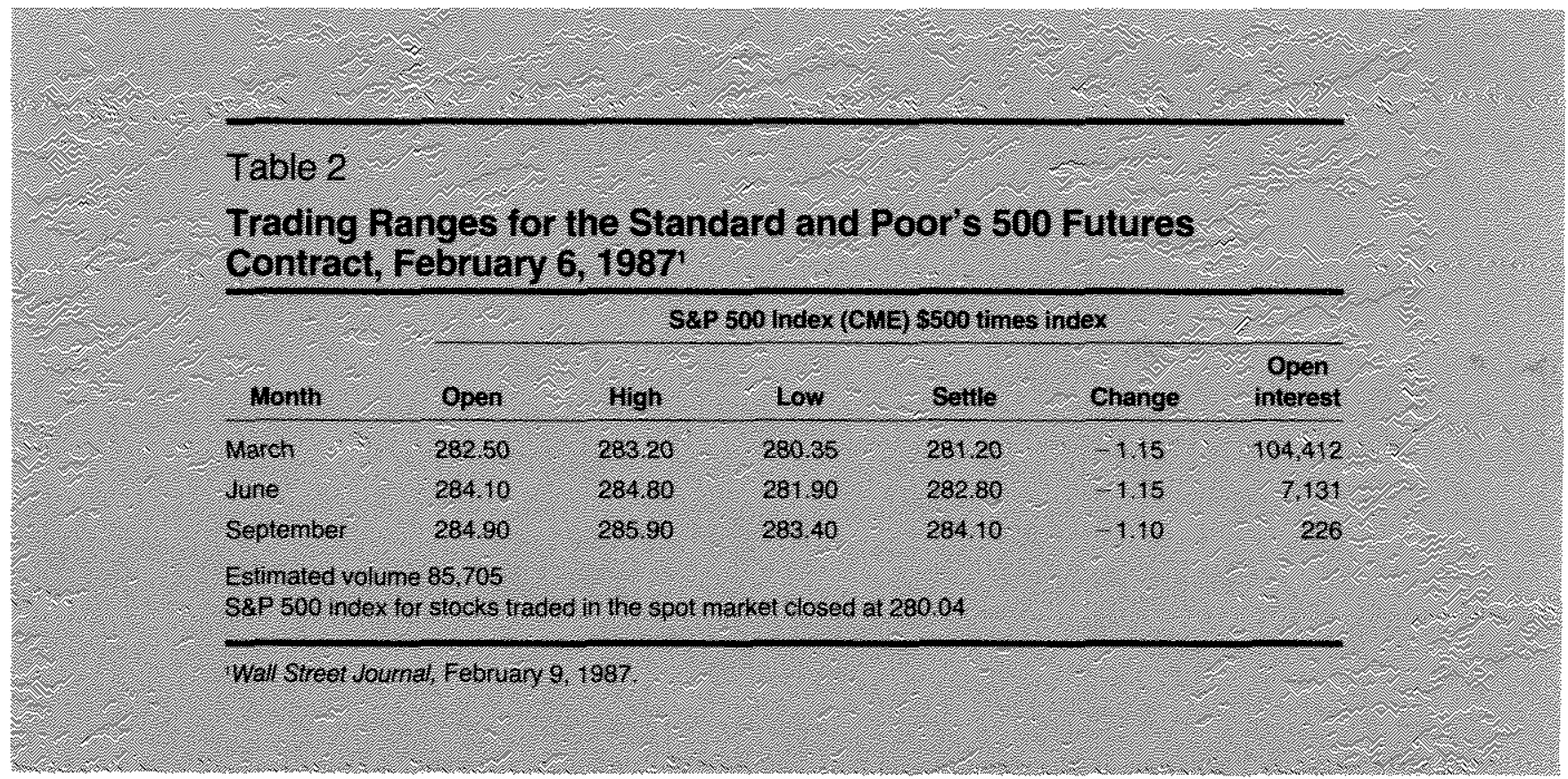

greatest in the March (nearby) contract. The market is relatively thin for the more distant contracts. The March contract opened at 282.50 and traded in the range of $283.20-280.35$ during the day. It closed at 281.20 . Since the value of the futures contract is $\$ 500$ times the index, the value of the March contract fluctuated between a high of $\$ 141,600$ and a low of $\$ 140,175$.

The value of the contract at the close was $\$ 140,600$ $(=\$ 500 \times 281.20)$ which represented a decline in its value of $\$ 575$ from its close at $\$ 141,175$ l $=\$ 500 \times$ 282.35 ) on the previous day. Traders who maintained long positions in this contract from the close on February 5 through the close on February 6 lost $\$ 575$ (= $\$ 500 \times 1.15)$ per contract and this amount was deducted from their margin accounts at the close of business on the 6 th. The reverse was true for traders who maintained short positions over the time interval.

\section{The Basis}

In addition to the information about the futures contracts, table 2 also indicates that the Standard and Poor's 500 Index for stocks traded on the spot market (S\&P Index) closed at 280.04 on February $6,1987$. Notice that this amount is different than the amounts recorded at the close for all three of the S\&P Futures contracts. The difference between the values of the S\&P Futures contracts and the S\&P Index is called the basis; it can be measured in dollars or index points. For example, at the February 6 close, the basis for the March contract was about $\$ 580 !=\$ 500128120-$
280.04 ]) or 1.16 index points ( $=281.20-280.04)$. The $^{9}$ The basis differs systematically across the three futures contracts; it is larger for more distant delivery months. The qualitative relationship between the prices of the S\&P Index and the three S\&P Futures contracts shown in table 2 is generally the one that is observed; that is, the value of the S\&P Futures is larger than the S\&P Index, and the difference increases for more distant contracts. A similar qualitative relationship exists between the other stock index futures contracts discussed above and their respective indexes. ${ }^{10}$

\section{WHAT DETERMINES THE BASIS?}

Whenever the basis deviates substantially from its equilibrium (or theoretical) value, profitable trading opportunities exist and arbitrageurs will attempt to capture them. Program trading is a method of discovering and exploiting these proft opportunities. Since the opportunities can arise when the equilibrium basis changes, it is important to understand how the equilibrium basis is determined and what things cause it to change.

\footnotetext{
The basis is "about" $\$ 580$ because the New York Stock Exchange closes at $4: 00 \mathrm{p} . \mathrm{m}$. Eastem Standard Time while the International Monetary Market closes 15 minutes later at 3:15 p.m. Central Standard Time.

10The Value Line Index may represent an exception to this general statement because of the averaging method used to calculate it. See Modest and Sundaresan (1983), pp. 19-20.
} 


\section{Futures: A General Discussion}

\section{What is a Futures Contract?}

A futures contract is an agreement between a seller and a buyer to trade some well-denned iten (wheat, corn, Treasury bills) at some specified future date at a price agreed to now, but paid in the future at the time of delivery.

There are three prices that must be kept straight when discussing these contracts: the spot price, the forward price and the futures price. The spot price is the price of the item today for delivery today. The price of the item in the future for delivery then is called the forward price. The price of the item today for delivery in the future is called the futures price. The futures price is specified in the futures contract. Essentially, it is a prediction of the forward price at maturity of the contract. ${ }^{3}$

\section{The Relationship Between Spot and Futures Prices}

The futures price of a commodity is equal to the spot price plus the cost of storage, insurance and foregone interest earnings associated with holding the good over the interval of the contract. A similar relationship exists between the spot and futures prices of financial instrunents (like stuck index. futures). Since the storage and insurance costs of holding these financial instruments is very low; however, the spread between spot and futures prices is largely determined by the interest cost.

\section{It Pays To Be Right}

Because futures markets typically are very active and are open to virtually anyone who can meet fairly modest capital requirement rules, futures prices represent an aggregate guess about the for-

See, for example, Working (1977), pp. 25-31.

2See, for example, Schwarz, Hill and Schneeweis (1986), pp. 326-46; Figlewski (1984), pp. 658-60; Cornell and French (1983), pp. 2-4; and Modest and Sundaresan (1983), pp. 22-23. ward price of the item. Of course, because it is a guess, it typically will be wrong. ${ }^{3}$ When the forward price that is realized is higher than the futures price that was agreed on, the buyer of the futures contract gains because he can purchase the item at the previously agreed upon futures price and immediately sell it at the higher current spot price. The seller of the futures contract loses because he must sell the item whose current spot price is higher than the price he previously agreed to sell at when he entered the futures contract. The reverse occurs when the forward price that is realized is less than the futures price that was agreed upon.

\section{Some Common Criticisms of Futures Markets}

It may appear that futures markets are simply a convenient form of gambling on forward prices. This has been a common criticism of futures markets along with the allegation that trading in futures increases price variation in the spot market. ${ }^{4}$ Speculative bets about price changes, however, are not unique to futures market trading. Economic decisions to buy or sell any storable good, by their nature, are speculative bets about the future course of the price. Furthermore, futures markets serve some valuable social functions such as allocating the consumption of storable goods over time as well as providing a means, through hedging, to reduce the risk of unexpected price changes..$^{5}$

3Wile typically wrong, the futures price will not consistently under-or over-predict the forward price. That is, the futures price is an unbiased predictor. If this were not true, it would be possible for traders to profit by exploiting the bias which would quickly eliminate it See Fama (1970).

4 See Working (1977), p. 293; Cagan (1981), p. 178; and Green (1986), p. 80 , for a discussion of these common criticisms of futures markets. This paper examines the second allegation for the case of stock index futures.

${ }^{5}$ For discussion of the social functions fulfilled by futures markets see Working (1977), pp. 25-31 and pp. 267-97; Alchian and Alen (1977), pp. 132-39; and Cagan (1981). 
The equilibrium difference between the $S \& P$ index and S\&P Futures (the equilibrium basis) is related to the equilibrium differences between the spot and futures prices of each of the stocks in the Stantard and Poor's Composite Index." Consequently, understanding the basis for individual stocks is helpful in analyzing the basis for S\&P Futures contracts.

\section{The Cost of Carry}

In equilibrium, the difference between the spot price of a stock and its expected price at some future date is determined by the cost of holding the stock Itermed "carrying the stock forward") from the present to the future date. This is called "the cost of carry."

As mentioned above, the storage and insurance costs of carrying stock is very low. However, a person who purchases stock gives up the rate of return he would have received if he invested in the next best available alternative. Economists call this foregone rate of return the opportunity cost of the investment; finance analysts call it the cost of capital. Both agree that it is equal to the market rate of interest (return) adjusted for the systematic risk associated with holding the particular stock. ${ }^{\text {.2 }}$

In order to focus on one thing at a time, suppose the stock that is being carried forward pays no dividends and that the cost of capital is 12.5 percent per year. ${ }^{13}$ Assume that it is now March 20, 1987 and the trader wants a forecast of the stock's forward price on June $19-91$ days from now. If the spot price of the stock on March 20 th is $\$ 50$, the foregone income that could be earned by investing the $\$ 50$ at 12.5 percent for three months is $\$ 50(1.125)^{25}-\$ 50=\$ 1.49$; this is the cost of carry. The March 20 th spot price plus the cost of carry is a forecast of the stock's forward price on June $19 / 91$ days from now). In this example, the forecast of the stock's price on June 19 th is $\$ 51.49 l=\$ 50.00+\$ 1.491$.

"The discussion focuses on the Standard and Poor's index not only for convenience but also because the Standard and Poor's futures contract is the most widely traded; it accounts for about 75 percent of all trading in stock index futures. See, Wall Street Journal (March 2. 1987).

'See Brealey and Meyers (1984), p. 133. Systematic risk is given by $\beta$, which is a measurement of the sensitivity of the investment's return with respect to the market return. Foughly, $\beta$ is the percentage change in the present value of the investment project divided by the percentage change in some market index of capital values such as the Standard and Poor's composite index ibid., pp. 166-67. The cost of capital, $i_{r}$ is calculated as $i=\beta\left(i_{n}-i_{1}\right)+i_{4}$, where $i_{m}$ and $i_{4}$ are the market and risk free rates of return.

${ }^{13}$ See Cornell and French (1983), Modest and Sundaresan (1983) and Figlewski (1984) for a formal analysis of the cost of carry.

\section{The Cost of Caryy wh Dividends}

Computing the cost of carry is only slightly more complicated if the stock pays dividends. Suppose that the stock in the previous example is scheduled to pay a dividend of $\$ .50$ on April 21,1987 . The dividend reduces the cost of carry by slightly more than $\$ .50$ because the dividend paid on April 21 can be invested between April 21 and June 19. Consequently, the value of the dividend as of Jume 19 is slightly higher than $\$ .50 .{ }^{14}$ For the example considered, the cost of carry is $\$ 50(1.125)^{25}-\$ .50(1.125)^{1.167}-\$ 50=\$ .98$. Notice that the dividend payment reduces both the cost of carry (from $\$ 1.49$ to $\$ .98$ i and the March 20 th forecast of the stock's price on June 19th (from $\$ 51.49$ to $\$ 50.98$ ).

\section{The Cost of Carry Is Lower for Nearby Deluvery Dates}

This discussion helps explain why the basis observed in table 2 is lower for futures contracts with nearby delivery dates. Because the holding period is shorter, the interest earnings foregone are less for nearby delivery dates. Similarly, as each contract approaches its delivery date, the cost of carrying the stock shrinks for the period remaining until delivery, other things the same; the cost of carry is zero on the delivery date. This is shown in figure 1. Figure 1 as-

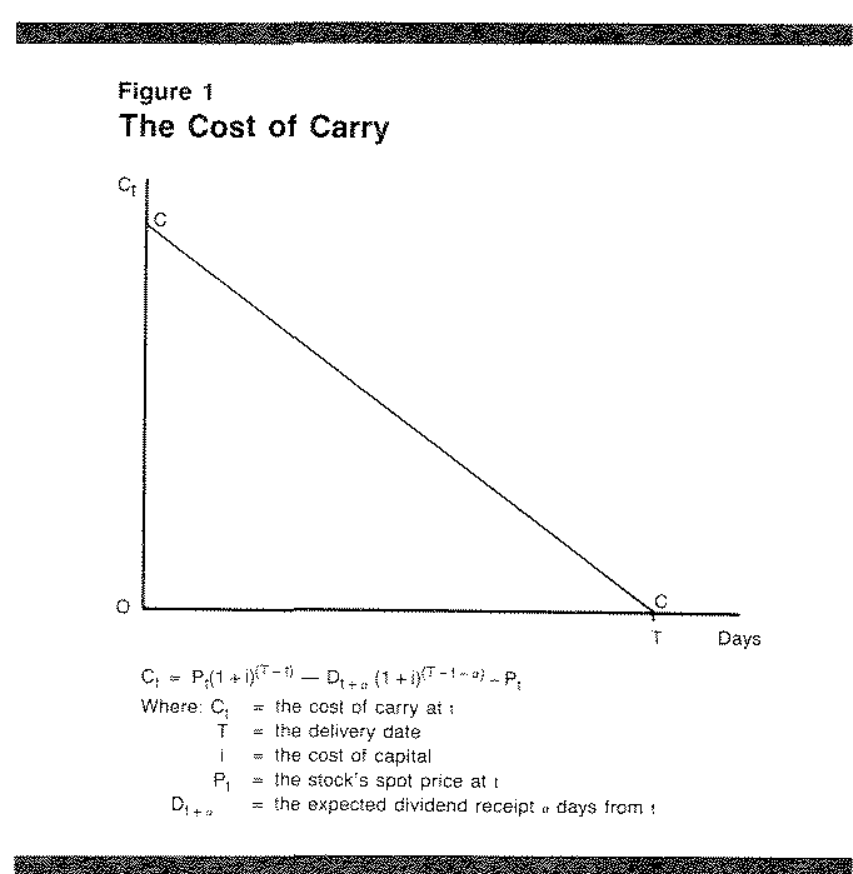

\footnotetext{
${ }^{14}$ This adiustment may seem trivial. When one is computing the basis for a stock portfolio that runs into the millions of dollars, as is the case for programmed trading, however, this adjustment can be very important. Notice that $.167=60 / 360$ where 60 is the number of days between the dividend receipt on Aprit 21 and June 19 .
} 
sumes that the cost of capital (i) and the dividends (D) the stock is expected to pay are unchanged during the holding period.

\section{The Cost of Carry Is Uncertain}

Since expected dividends can change during the holding period, the cost of carry is not known with certainty. The only thing known with certainty is that the cost of carry will be zero on the day the futures contract is scheduled for delivery.

A change in the expected dividend will cause the line showing the cost of carry in figure 1 to rotate through the point labeled $T$. An increase in $D$ causes the cost of carry to rotate downward, while a decrease in $D$ causes the cost of carry to rotate upward. ${ }^{15}$

\section{The Cost of Carry and the Basis}

The expected cost of carry and the basis are closely related ${ }^{16}$ To illustrate this for a simple case, suppose for a moment that the S\&P Index contains only one share of stock. Suppose that the March 20th spot price of the share is $\$ 50$ the level of the index is 50 ) and that

\footnotetext{
15. The cost of carry generally will vary with changes in the cost of capital, i. Whether a direct or indirect relationship exists, however, is problematic. To see this, let

(1) $E(t) P(T)=F(t)=P(t) e^{(i-\delta) / T-t k}$

(2) $P(t)=\frac{E(t) \pi}{i}$

(3) $B(t)=F(t)-P(t)$.

where

$E(t) P(T)=$ The period $t$ expectation of the forward price at $\mathrm{T}$.

$F(t)=$ The futures price in period t of a contract dated for delivery at $\mathrm{T}$.

$P(t)=$ The spot price in period $t$.

$i=$ The cost of capital.

$\delta=$ The expected dividend rate.

$E(t) \pi=$ The period $t$ expectation of the perpetual stream of profits ( $\pi$ ) assumed to be of constant amount in each period.

$B(t)=$ The basis in period $t$.

Substitution gives

$$
\begin{aligned}
& B(t)=\frac{E(t) \pi z}{i}\left[\mathrm{e}^{(i-4) \pi(T-1)}-1\right] \\
& \frac{\partial B(t)}{\partial i}=-\frac{E(t) \pi}{i^{2}}[\quad]+\frac{E(t) \pi(T-t) e^{(i-8)(T-t)}}{i}
\end{aligned}
$$

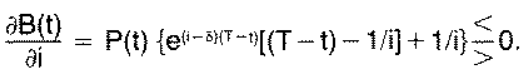

${ }^{36}$ See, for example, Cornell and French (1983), pp. 2-3. The example assumes that the equilibrium spot price is given so that the futures price adjusts to the cost of carry. In fact, spot and futures prices are determined simultaneously.
}

the expected cost of carry is $\$ 1.50$ per share for the next three months (from March 20th to June 19th). If the current price of the S\&P Futures contract dated for June delivery is $\$ 52.00$, the $\$ 2.00$ basis $(=\$ 52.00-$ $\$ 50.00$ ) exceeds the $\$ 1.50$ expected cost of carry. The arbitrageur will sell (go short in) June futures at a price of $\$ 52.00$ per contract and buy (go long in) spot shares of the stock at $\$ 50.00$. He does this because he expects the price of the June futures to fall to $\$ 51.50$ the spot price plus the expected cost of carry). At that price, he can cover his futures position (by purchasing a June futures/at a cost of $\$ 51.50$ per contract. His gain is $\$ .50$ per contract - the difference between the sale price of the futures contract $(\$ 52.00)$ and the cost of covering the contract $(\$ 51.50) .{ }^{17}$

The arbitrageur's long, spot position serves to hedge his short, futures position against unexpected changes in the price of the stock. For example, suppose both the June futures price and the spot price rise by $\$ 3.00$ immediately after the arbitrageur sells the futures and buys the stock spot. The June futures price rises to $\$ 55.00$ per contract and the spot price increases to $\$ 53.00$ per share. After the price change, the basis $(\$ 2.00=\$ 55.00-\$ 53.00)$ still exceeds the expected cost of carry $(\$ 1.50)$ by $\$ .50$ so the arbitrageur expects the price of the June futures to fall to $\$ 54.50$ per contract ${ }^{18}$ At that price he will cover his short position at a loss of $\$ 2.50$ per contract $l=\$ 52.00-$ \$54.50). This loss, however, is more than offset by his $\$ 3.00$ per share gain $(=\$ 53.00-\$ 50.00)$ on his spot position. His net gain is $\$ .50(=\$ 3.00-\$ 2.50)$ - the same as in the previous case. By hedging in the spot market, the arbitrageur protects the expected gain from unexpected changes in the price of the stock.

On the other hand, suppose the price of the June futures is $\$ 51.00$. In this case, the $\$ 1.00$ basis $(=\$ 51.00$ $-\$ 50.00$ ) is less than the $\$ 1.50$ expected cost of carry. The arbitrageur will short the stock and go long in the June futures. The arbitrageur expects the price of the June futures to rise to $\$ 51.50 \mathrm{per}$ share. At that price, he will sell his June futures contract at a gain of $\$ .50$ per contract $(=\$ 51.50-\$ 51.00)$. Again, his short spot position hedges his expected gain against unexpected changes in the price of the stock. Since virtually any-

\footnotetext{
${ }^{17}$ The arbitrageur always has the alternative of holding the stock until the June delivery date of the futures contract at which time the stock is sold and the proceeds are used to settle the futures contract. Since the arbitrageurs' investment in the stock is expected to be $\$ 51.50$ per shaze as of the settlement date $(=\$ 50.00+\$ 1.50)$, expected profits are $\$ .50$ per share.

${ }^{18}$ In fact, if the interest rate does not change, the expected cost of carry will rise slightly because of the higher spot price.
} 
Figure 2

The Cost of Carry and Transaction costs

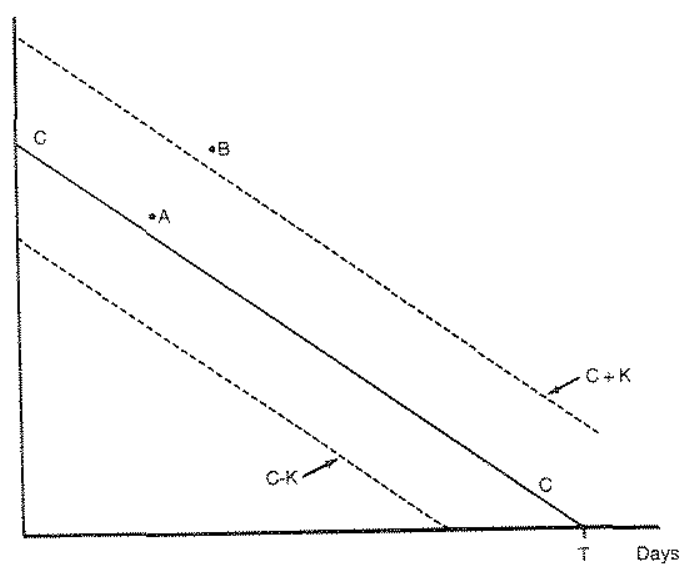

A profitable trading oppontunity sxists when:

1) The basis is greater than the cost of cary plus transaction cast

$(\mathrm{C}+K)$

2) The basis is less than the cost of carry minus nansaction cost $(\mathrm{C}-\mathrm{k})$

where:

$0=$ the cost of carty

$K$ I transaction cosi

one can take advantage of these mading opprtuniries, large deviations of the basis from the cost on cany do not pensist.

Small differences between the basis and cost of carry may persist, however, if the transactions cost of making the appropriate trades is greater than the expected gain. In terms of figure 1, transaction costs can be represented by bands around the line representing the cost of cary. This is shown in figure 2 . The vertical distance between the solid line and the dashed lines represent the transaction cost. If the basis deviates from the cost of carry but remains whin the bands las represented by point $A$, for examplet, no profitable arbitrage trading is possible. If the basis moves outside the bands to point $B$, for examplet, arbitrageurs will exploit the profiable trading opportunities caused by this large discrepancy. The trading will continue until the basis has been driven back within the bands.

\section{TTADING STOCK TNDEX FUTURES}

The analysis discussed above is directy applicable to trading among the stocks that make up the S\&P Index and the S\&.P Futures contract. Rather than one stock, however, the S\&.P Index represents a basket of 500 stocks. The $\$ \& P$ Index multiplied by $\$ 500$ is analo- gous to the spot price of the stock in the previous discussion and the S\&P Futures multiplied by $\$ 500$ minus the $\$ \& . P$ Index multiplied by $\$ 500$ is the basis. ${ }^{*}$ In principle, the cost of cary is calculated the same way as for an individual stock. There are two important practical differences, however.

First, because the $s e p$ Index represents a welldiversified basket of stocks, it typically is assumed that the risk of unanticipated changes in the value of this basket is roughy equal to the market's risk. Consequently, the cost of capital for the S\&P Index is the markef rate of return,

A second important practical difference is that the trader must track the dividend policies of 500 com panies and the dates on which the shares frade exdividend in order to compute the cost of carry. These calculations must be made quickly and accurately because proftable trading opportunities that result from differences between the basis and cost of cary persist only for a short time.

Because both the monitoring and transaction costs increase with the number of companies included in the arbitrage portfolio, traders do not track all 500 stocks in the S\&. Index. Instead, they identify a subset of the 500 stocks whose combined value has closely followed the value of the index in the past." Thus traders accept some additional risk because the values of their narrower portfolios are unlikely to move pre cisely with the s\&p Index. The added risk is accepted to reduce the expense of tracking the cost of carry for the broader portfolio.

Of course, computer programs are another way to reduce the expense of calculating and continuously updating the cost of carry as new infomation becomes available. "Program trading" refers to computer programs that compute the cost of carry and signal profitable trading opportunities. Programmed trading is a less costly (more efficient) method of exploiting profitable trading opportunities between the spot and futures markets.

\section{WDDE WUTURE AND TIE

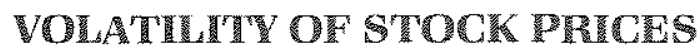

Various commentators have alleged that trading between the stock index futures market and the spot

${ }^{19}$ Recall that the value of an S\&P Futures contract is $\$ 500$ times the index. See table 1 .

20 That is, $\beta$ is assumed to equal 1 so that $i=\beta\left(i_{m}--i_{i}\right)+i_{i}=i_{m}$.

2: See Schwarz, Hill and Schneeweis (1986), p. 91. 


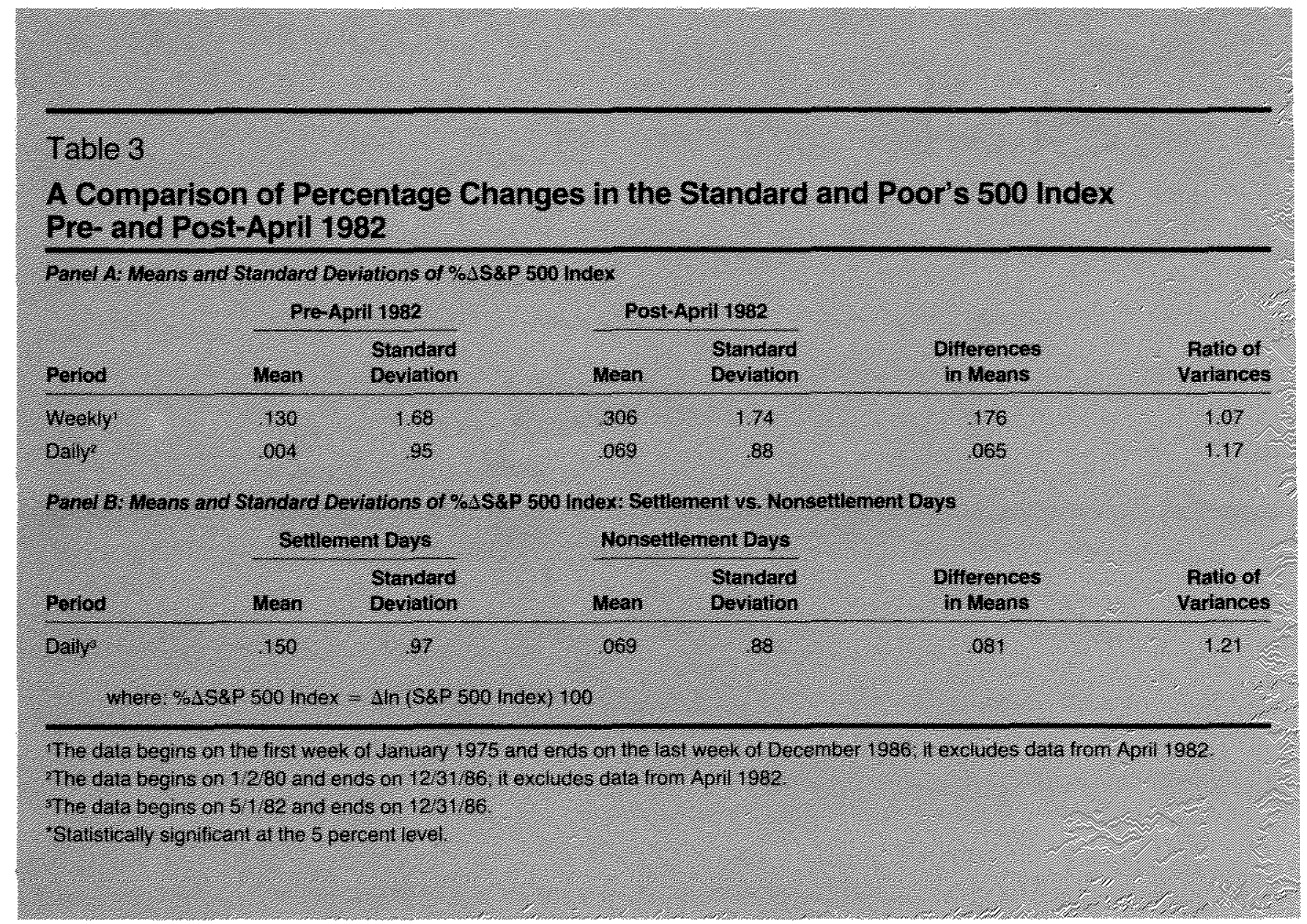

makket for stocks has increased the volatility of stock prices. This criticism has a long history. ${ }^{2 a}$ Our analysis, however, does not imply that stock prices will exhibit greater volatility as a result of this trading. Rather, it suggests that such trading results in a closer correspondence between prices in the spot and futures markets. Since there is no reason to suspect, a priori, that this trading increases the volatility of prices in the spot market, we must rely on the data to help answer this question. ${ }^{23}$

The following analysis addresses three key questions: 1) Has stock price variability increased since stock index futures began lading early in 1982? 2) Are stock prices more variable on days when futures contracts are scheduled for delivery triple witching days?? 3) Is stock price variability related to trading activity in stock index futures?

\footnotetext{
22See Working (1977), pp. 267-97.

rabid., p. 295.
}

\section{Percentage Changes th the Sep sind:

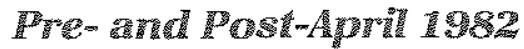

The Standard and Poor's futures contract began trading on April 21, 1982. This is the most active contract and accounts for about 75 percent of all trading in stock index futures. ${ }^{24}$

Table 3 compares the period before and after April 1982 using weekly and daly percentage changes in the Standard and Poor's 500 Index. Percentage differences are employed to control for the general increase in the level of the index from 1975 through 1986.

Panel $A$ of table 3 examines the mean and standard deviation of weekly and daily percentage changes in

\footnotetext{
${ }^{24}$ See, Wall Street Joumal (March 2, 1987).

25The index rose from an average level of 86.18 in 1975 to an average level of 236.34 in 1986. A one-point change in the index represented a much larger percentage change in 1975 (about 1.2 percent) than a one-point change in 1986 (about 4 percent).
} 
the index. As indicated, the mean of the weekly percentage change in the index prior to April 1982 was .130 percent. After April 1982, the mean rose to .306 percent, an increase of $\mathbf{1 7 6}$ percentage points in the later period. In the case of the datly data, the mean of the daily percentage change increased by .065 percentage points in the later period. Neither increase is statistically significant at conventional confidence levels ( $t$-scores are 1.30 and 1.39 , respectively). The differences in the means before and after April 1982 could easily have been produced by chance variation in the data.

Comparing the means, however, masks much of the variation in the data, because increases in the index are offset by decreases when the mean is computed. The standard deviation is a better indicator of variation because it measures the spread in the data around the mean. ${ }^{26}$ For example, the standard deviation of the weekly data before April 1982 is 1.68 . If these percentage changes in the index are normally distributed, about 67 percent of the weekly observations fall within the range of $.13 \pm 1.68$ for -1.56 percent to 1.80 percent). The standard deviation of the weekly data after April 1982 is 1.74 which is about the same as for the earlier period. In fact, the two are not significantly different in a statistical sense (the ratio of the variances $=1.07$ ). A similar conclusion holds for the daily data. In this case, the standard deviation is somewhat smaller in the more recent period, but is not significantly smaller in a statistical sense ${ }^{z z}$

Panel $B$ of table 3 compares variation in the index on days when S\&P 500 Futures contracts mature isettle ment days) to variation on all other days (nonsettlement days) for the post-April-1982 period. In the case of settlement days, the data are percentage changes in the S\&P 500 Index from the close on the day before a settlement day to the close on the settlement day. For nonsettlement days, the data are percentage changes in the daily closing value of the index excluding the changes on settlements days. As indicated in panel $B$, the mean percentage change is larger on settlement than on nonsettlement days; but the difference beween the two is not statistically significant at conventional confidence levels ( $t$-score $=.36$ ). Similarly, the

\footnotetext{
26 See Wonnacott and Wonnacott (1977), pp. 24-25.

${ }^{27}$ In addition, both the mean absolute devation (MAD) and mean absolute value (MAV) of the weeky and daly percentage changes in the index were examined for the two periods. Like the standard deviation, these measure variation and, for this data, each measure tells a similar story. As in the case of the standard deviation, both the MAD and MAV are slightly higher for the weekly data (about 2 percent higher) and slightly lower for dally data (about 11 percent lower) in the post-April 1982 period.
}

standard deviation is lafger on settlement days $1.97 \mathrm{vs}$. .88), but is not significantly larger in a statistical sense the ratio of the variances $=1.21$ ). Thus, the data in table 3 suggest that the share prices of companies included in the $5 \&$.P Index did not become statistically more variable on avefage after the S\&P Futures contract began trading nor were they more variable on settlement (triple witching) days.

\section{Intra-Day Variation: Pre- and Post-April 1982}

The above data measures price variation from dayto-day. Some commentators have expressed concem about intra-day movements in stock prices. The data in panel A of table 4 examine one measure of the intraday price spread in the S\&.P Index for pre- and postApril 1982 data: the difference between the daily high and low of the index divided by the close and multiplied by $100^{28}$

Panel A indicates that the mean intra-day spread was 2.03 percent before April 1982 and 1.38 percent after. The difference, -.65 percent, is statistically significant (t-score $=17.29$ ) and indicates that the intraday percentage spread declined after April 1982.

Panel B examines whether the post-April 1982 intraday price spreads have been unusually large on triple witching days." The data indicates that the mean intra-day percentage spread is slightly larger on triple witching days than on nonsettlement days $(1.56 \mathrm{vs}$. 1.38); the difference, however, is not statistically significant at conventional confidence levels (using the pooled variances, the $t-s c o r e=1.48$.

To summarize, the data in table 4 indicate that there was a statistically significant decline in the intra-day percentage price spread in the post-April 1982 period. There was no statistically discernible difference, however, between the spreads on triple witching days vs. other post-April-1982 trading days.

\section{Price Variation and Trading Activity in S\&P Futures}

The data in table 5 help assess whether stock price variability is related to trading activity in S\&P Futures contracts. The data are correlation coefficients for daily trading volume in S\&.P Futures contracts (V) and

\footnotetext{
Scaling the difference between the high and low by the daily low rather than the close produces virtually identical results.

29See, for exarpple, Stoller, and Laderman and Frark (September 29, 1986), pp. $96-97$.
} 


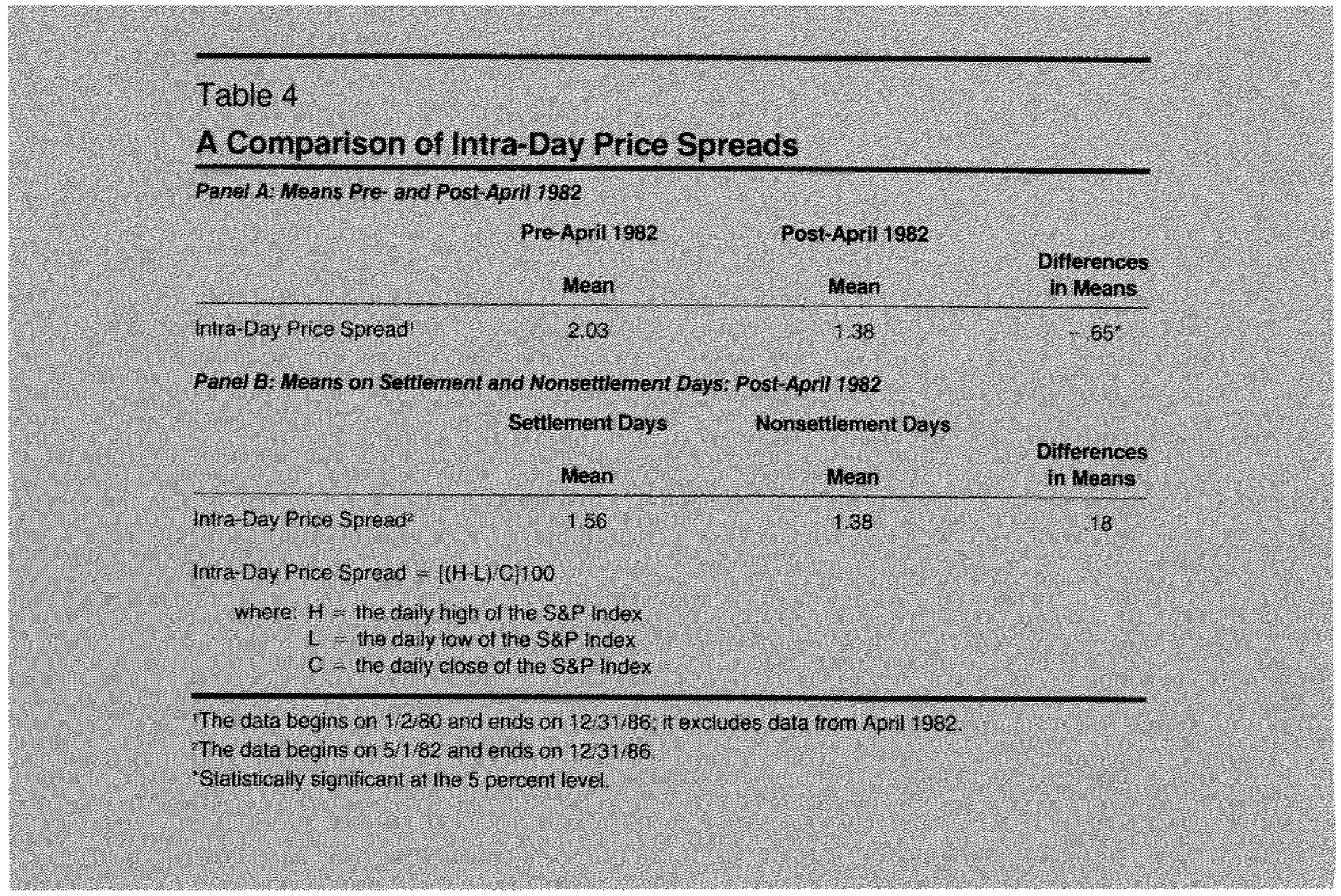

several measures of price variation in the S\&P Index: the daily percentage change in the S\&P Index $(\dot{P})$, the absolute value of the daily percentage change in the $S \& P$ Index $(A \dot{P})$ and the intra day percentage price spread (S). Respectively, these correlations indicate whether the volume of trades in S\&.P Futures generally is associated with an increase or decrease in the $S \& P$ Index, larger or smaller changes (either up or down) in the S\&P Index, and larger or smaller intra-day price spreads.

An examination of table 5 indicates that the coefficient of corvelation for $V$ and $\dot{\mathbf{P}}$ is not significantly different from zero in a statistical sense. The same holds in the case of $\mathrm{V}$ and $A \dot{P}$. This data suggests that neither the direction nor the magnitude of changes in the S\&P Index are associaled with trading volume in the S\&.P Futures market. The coefficient of correlation for $V$ and $S$, however, is negative and significantly different from zero in a satistical sense; larger trading volume in S\&. Futures contracts generaliy was associated with smaller intra-day price spreads. The table 5 data are not consistent with the claim that trading activity in S\&P Futures was associated with increased variation in the S\&P Index.

\section{COPCIUSOLN}

Numerous commentators have claimed that stock prices have been more variable since stock index fum tures contracts began trading. The alleged increase in volatility led to both closer scrutiny of the market by the Securities and Exchange Commission and calls for legislative action. The presumed increase in stonck price volatility has been attributed to program . ned trading - the practice of tradin, between the spot and futures markets for stocks. While this trading strategy is not new, the introduction of stock index futures contracts around 1982 and the application of computer programming techniques to trigger trades beween the markets are novel.

This paper discusses the theory that underlies programmed trading and examines various measures of stock price variation. The results of the analysis are not consistent with the claim that trading activity in the S\&P Futures contract is associated with increased price variation in the spot market for sturks.

While closer scrutiny and regulation of trading in stock index futures markets may be justified on other grounds, the evidence presented here suggests that 


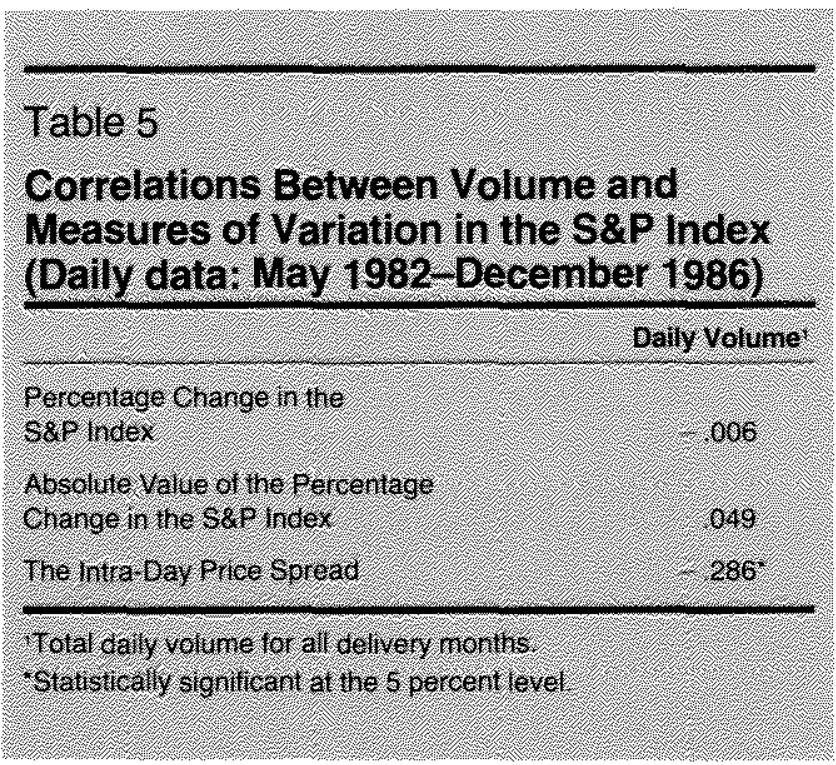

regulation based on the proposition that it has increased price volatility in the spot market would be misdirected.

\section{TRERTRNCES}

"Abreast of the Market." Wall Street Journal (January 26, 1987).

Alchian, Armen, and William R. Allen. Exchange and Production: Competition, Coordination and Control, 2nd. ed. (Wadsworth, 1977), pp. 131-39.

Belongla, Michael T. "Commodity Options: A New Rissk Management Tool for Agricultural Markets," this Review (June/July, 1983), pp. 5-15.

Black, Fischer, and Myron Scholes. "The Pricing of Options and Corporate Liabilities." Journal of Political Economy (May/June 1973), pp. 637-54.

Brealey, Fichard, and Stewart Meyers. Principles of Corporate Finance (McGraw-Hill, 1984).

Cagan, Phillip. "Financial Futures Markets: Is More Regulation Needed?" Journal of Futures Markets (Vol. 1, no. 2, 1981), pp. $169-92$.
Cinat, E. Mine. "Evidence on the Effect of Option Expirations on Stock Prices," Financial Analysts Joumal (January/February 1987), pp. 55-57.

Clark, Lindley H. Jr. "Where is the Soaring Stock Market Leading Us?" Wall Street Journal (January 27, 1987).

Comell, Bradford, and Kenneth R. French. "The Pricing of Stock Index Futures," Journal of Futures Markets (Spring 1983), pp. 114

Fama, Eugene F. "Efficient Captal Markets: A Review of Theory and Empirical Work." Journal of Finance, Papers and Proceedings (May 1970), pp. 383-417.

Figlewski, Stephen. "Hedging Performance and Basis Risk in Stock Index Futures," Journal of Finance (July 1984), pp. 657-69.

Galbraith, John Kenneth. The Great Crash (Houghton Mifflin, 1955).

Green, Edward J. "Financial Futures and Price-Level Variability," Financial Futures and Options in the U,S. Economy (Board of Governors of the Federal Reserve System, 1986), pp. 79-89.

Kawaller, fra G. "The Rudiments of Options on Futures: A Primer for the Uninitiated," Market Perspectives (Chicago Mercantile Exchange, 1986).

Laderman, Jeffrey M, and John N. Frank. "How Chicago Zaps Wall Street," Business Week (September 29, 1986), op. 92m102.

Laderman, Jeffrey M., et. al. "Those Big Swings on Wall Street," Business Week (April 7, 1986), pp. 32-36.

McMurray, Scott. "Chicago Merc Seeks to Curb Market Swings," Wall Street Journal (Febrtiary 12, 1987).

Modest, David M., and Mahadevan Sundaresan. "The Relationship Between Spot and Futures Prices in Stock Index Futures Markets: Some Preliminary Evidence, "Journal of Futures Markets (Spring 1983), pp. 15-41.

Schwarz, Edward $W_{\text {. }}$ Joanne $M$. Hill, and Thomas Schneeweis. Financial Futures (Dow Jones-Irwin, 1986 ).

"Stocks End Day Mixed as Market Recovers From the Roller Coaster," Wall Street Jounnal (January 27, 1987).

Stoll, Hans R., and Robert E. Whaley. "Program Trading and EXpiration-Day Effects," Financial Analysts Journal (March/April 1987), pp. 16-28.

Stoller, Stephen D. "The $\$ 18$ Billion Bet," Barron's (February 9. 1987), p. 24

Working, Holbrook. Selected Writings of Holbrook Working (Chicago Board of $\mathrm{w}$ rade, 1977).

Wonnacott, Thomas H., and Ronald J. Wonnacott, Introductory Statistics for Business and Economics (John Wiley and Sons. 1977), pp. 22-25. 